\title{
The Importance of the Creation of CEFTA-2006 for the Western Balkans' Trade Exchange of Goods
}

\author{
Kikerkova Irena \\ Ss Ciril and Methodius University, Skopje, Republic of Macedonia
}

\begin{abstract}
By integrating 32 bilateral free trade agreements, CEFTA-2006 became the first multilateral free trade agreement of the Western Balkan countries. Signed at the end of 2006, it was supposed to establish a free trade area among the following member-states: Albania, Bosnia and Herzegovina, Croatia, Macedonia, Moldova, Monte Negro and Serbia. ${ }^{1}$ The free trade area was supposed to be fully functional by the end of 2010 and should provide trade liberalization by elimination of all tariff and non-tariff barriers for agricultural and non-agricultural goods, as well as trade facilitation by simplification of rules of origin and transit procedures. It should also provide mutual recognition of national sanitary, phytosanitary and technical standards. The free trade area should also enable free trade of services, full protection of intellectual rights, fair rules of public procurement procedures and liberalization of capital investment. The beginning of the creation of the free trade area of the Western Balkan countries created a positive effect upon the increment of the trade exchange of goods among its member-states. However, the weak individual economic capacity of each of them immediately caused a decrement in the exports of goods towards trading partners out of CEFTA-2006. Positive effects realized in the beginning of the creation of the free-trade area were very soon annulated by the influence of the economic crises in 2008. At present, the region experiences a slight, but very slow recovery.
\end{abstract}

Keywords: CEFTA-2006, Republic of Macedonia, free trade area, trade liberalization, trade facilitation, trade exchange of goods

\section{Introduction}

Looking back through history, the Balkan region was highly economically and politically integrated. Economic and political divisions of the Balkans started about a hundred years ago, while the Western Balkans region experienced its full disintegration some 20 years ago. This process seriously affected the economies of the newly established states in the region. The disintegration did not happen in a peaceful manner which caused a serious damage in several economies of the Western Balkans region. The armed conflicts were closed down about a decade ago. However, the economic recovery of the economies and the region as a whole was far from satisfactory. Political and economic division of the region prevented the reestablishment of the previous existing

Kikerkova Irena, Ph.D., Faculty of Economics, Ss Ciril and Methodius University.

Correspondence concerning this article should be addressed to Kikerkova Irena, Blvd. "Krste Misirkov bb, 1000 Skopje Republic of Macedonia. E-mail: irena@eccf.ukim.edu.mk.

${ }^{1}$ According to the UN Resolution, Kosovo is a member of CEFTA-2006 as a territory which is an integral part of Serbia. 
supply and distribution chains. The trade exchange of goods was prevented by the establishment of various trade and non-trade barriers, while the creation of new borders slowed down and further complicated transit procedures.

The Macedonian economy was severely affected by the disintegration of the region, especially by the dissolution of the former Yugoslav state. Within the Yugoslav state, the Macedonian economy was structured in order to serve the industrial production of the rest of the republics as a raw-material base. Almost $75 \%$ of the total Macedonian production was realized on the Yugoslav market. At the same time, the Macedonian industry was heavily dependent on the import of energy and raw-materials from the ex-Yugoslav republics for the needs of its own manufacturing industries. Therefore, with the fall of the ex-Yugoslav state, the Republic of Macedonia was immediately cut off from its most important suppliers, as well as from its most important markets.

Soon the country tried to bridge over this unexpected gap by signing bilateral free trade agreements with all the entities that derived from the ex-Yugoslav state, and continued to sign bilateral free trade agreements with the rest of the countries within the Balkan region. Being not a member of the WTO until April 2003, Macedonia was prevented to negotiate any trade liberalization on multilateral basis, and had to use only bilateral trade negotiations as an instrument for regulation of the trade exchange of goods. By signing 11 from a total of 32 signed bilateral free trade agreements in the region, Macedonia became a leader in trade liberalization negotiations on the Balkans before gaining the WTO membership. At the same time, the country was ranked on the 40th place among the most trade opened economies in the world on a list of 141 countries by the Italian International Academy of Interdisciplinary Studies. On this list, only Slovenia and Bulgaria were ranked better than Macedonia from all of the Balkan countries (on the 19th and on the 27th place, respectively) (The Ministry of Economy of the Republic of Macedonia \& USAID, 2005).

Nevertheless, the Macedonian trade reintegration within the region went on slowly and unsatisfactory. By 2001, the trade exchange of goods with Western Balkan countries reached 23\% of the total Macedonian foreign trade exchange of goods. However, right after signing the Stabilization and Association Agreement with the EU, the Macedonian trade exchange of goods experienced a strong trade diversion effect towards the EU trade parterns. The trade diversion effect, as well as the weak economic capacity of the country, caused a sharp fall in the trade exchange with the neighboring countries and the Western Balkan region happened to create only $8 \%$ of the total Macedonian trade exchange in 2006 (Kikerkova, 2009). The same negative tendencies were also experienced by other Western Balkan countries right after signing their own Stabilization and Association Agreements with the EU. By the end of 2006, trade liberalization with the EU resulted in diversion of over half of the total exports and imports from the Western Balkans. At the same time, there was a total neglect of the trade cooperation among the countries within the region. The increment of the trade exchange of goods among trading partners from the EU and from the Western Balkans could be even greater if there was no problem of rules of origin. All of the Western Balkan countries, being import dependent economies, have difficulties in proving national origin of their most important export items. This is a serious problem as by not proving national origin of their products, they are excluded from the preferential rules of importation on the Internal Market of the EU. Therefore, the EU insisted on a creation of at least a free trade area among the Western Balkan countries, which would enable circumvention of the existing rules of origin and implementation of the so called "diagonal cumulation".

Finally, with a strong support of the EU, the Western Balkan countries decided to establish a free trade area and named it CEFTA-2006. The free trade area was designed to eliminate all tariff and non-tariff barriers for 
agricultural and non-agricultural goods, but also to provide harmonization of sanitary and phytosanitary, as well as technical standards of its member-states. It should also provide free movement of services and capital investment, as well as guaranties of investors' rights. The free trade area should provide fair rules on public procurement procedures, and trade facilitation by simplification of rules of origin and transit and transportation procedures. The agreement was signed by Albania, Bosnia and Herzegovina, Croatia, Macedonia, Moldova, Monte Negro and Serbia and was supposed to provide full establishment of the free trade area by the end of $2010 .^{2}$

\section{Trade Exchange of Goods of the Republic of Macedonia With CEFTA-2006 Member-States}

The possibility for adequate analyzes of the mutual trade exchange of goods within CEFTA-2006 is very limited due to the fact that its member states have not accepted a common statistical methodology on regular statistical reporting on their mutually effectuated trade exchange of goods. The statistical reporting of some of the member-states, for example, Macedonia, is still done in dollars, while the rest of the members in the meanwhile accepted to report their data in euros. What is even more important is that the countries in the region, with exclusion of Croatia and Kosovo, have not accepted to create a special database on the trade exchange of goods within CEFTA-2006. For example, Macedonia is reporting on trade exchange of "Western Balkan countries", Bosnia and Herzegovina on "European countries in development", while Serbia has the category MERKOSUR, although it does not have any trade with this region, does not report on CEFTA-2006 trade exchange at all (Handziski, 2010).

There is also a significant discrepancy in the so called mirror statistical evidence of export and import flows of the member states which causes doubts that differences in the reported data are not a result only of differences in the statistical methodology, but there might be also other hidden issues. However, the greatest obstacle for adequate analyzes of the trade exchange of goods within CEFTA-2006 is the fact that the trade statistics within the region is not fully publicly available (Handziski, 2010). Having all these difficulties in mind, this article is going to analyze only data available from statistical data sources in Macedonia.

According to the Statistical Office of the Republic of Macedonia, the trade exchange of goods of the country with CEFTA-2006 trade partners started to record positive trends immediately after the signification of the agreement. The total Macedonian export to CEFTA-2006 member states almost doubled in the period from 2006-2008. Similar tendencies were also registered on the import side. It is very important to note that Macedonia managed to realize a slight trade surplus in the trade exchange of goods within the region. This was very stimulating for the Macedonian exporters, as the country traditionally suffered from a deficit in its balance of payments, mainly due to the trade balance deficit, which reached the amount of almost 2.5 billion dollars at the end of 2008. At the same time, the surplus realized with CEFTA-2006 trade partners amounted 647.27 million dollars (see Table 1) (Retrieved from www.mchamber.mk).

The economic crises that took off mostly during 2009 caused a decrement of the total trade exchange of goods from Macedonia. The crises had especially negative effect upon the Macedonian exporters, as they were dependant on exports of metals, textiles, agricultural products and food, and oil and fuels. Except the oil and the fuels, all of the most important export items for the Macedonian economy happened to belong to the so called

\footnotetext{
${ }^{2}$ According to the UN resolution, Kosovo is a member of CEFTA-2006 as a territory which is an integral part of Serbia.
} 
sensitive product groups and suffered from severe fall down of prices during the crises. The total amount of Macedonian imports also decreased, however this decrement was not up to the level of the decrement on the export side. At the end of 2009, the total trade deficit of the Macedonian economy amounted 2.3 billion dollars.

Table 1

Trade Exchange of Goods of the Republic of Macedonia With CEFTA-2006 for the Period 2006-2008 (in Million Dollars)

\begin{tabular}{lcll}
\hline Year & Total export & Total import & Total trade exchange with CEFTA-2006 \\
\hline $2006^{*}$ & 787.51 & 400.19 & $1,187.70$ \\
2007 & 991.72 & 613.70 & $1,605.42$ \\
2008 & $1,408.95$ & 761.68 & $2,170.63$ \\
2009 & $1,000.42$ & 600.36 & $1,600.78$ \\
2010 & $1,018.32$ & 628.11 & $1,646.43$ \\
\hline
\end{tabular}

Notes. "Data for 2006 are given for comparison purposes. The implementation of the Agreement between Macedonia, on the one hand, and Albania, Kosovo, Moldova and Monte Negro, on the other, began on the 26th of July, 2007; with Croatia on the 22nd of August, 2007; with Serbia on the 24th of September, 2007 and with Bosnia and Herzegovina on the 22nd November, 2007. Data consider the whole year period of time (Statistical Office of the Republic of Macedonia, 2008).

From the range of partners which have agreed a preferential trade regime with our country, the crises had especially affected the Macedonian trade exchange with the EU and CEFTA-2006. Table 2 presents data on realized trade exchange of goods under preferential trade regime in 2008 and 2009 by regions and partner-countries.

Table 2

Trade Exchange of Goods of the Republic of Macedonia Under Preferential Trade Regime (in Million Dollars)

\begin{tabular}{|c|c|c|c|c|c|c|c|c|c|}
\hline \multirow{2}{*}{ Region/country } & \multicolumn{3}{|c|}{ Export } & \multicolumn{3}{|c|}{ Import } & \multicolumn{3}{|c|}{ Total } \\
\hline & 2008 & 2009 & Index & 2008 & 2009 & Index & 2008 & 2009 & Index \\
\hline EU 27 & $2,366.8$ & $1,521.5$ & 63.9 & $3,294.1$ & $2,631.7$ & 79.9 & $5,661.0$ & $4,144.2$ & 73.2 \\
\hline CEFTA-2006 & $1,413.9$ & $1,000.4$ & 70.7 & 762.6 & 600.4 & 78.7 & $2,176.5$ & $1,600.8$ & 73.5 \\
\hline EFTA & 17.5 & 19.1 & 109.1 & 297.4 & 126.3 & 42.5 & 314.9 & 145.5 & 46.2 \\
\hline Turkey & 31.6 & 40.8 & 129.1 & 268.7 & 250.7 & 93.3 & 300.3 & 291.5 & 97.1 \\
\hline Ukraine & 2.9 & 10.1 & 343.2 & 202.9 & 84.5 & 41.6 & 205.9 & 94.6 & 45.9 \\
\hline
\end{tabular}

Data presented in Table 2 confirm the decrement of about $30 \%$ of the Macedonian trade exchange with CEFTA-2006 trade-partners in 2009 in comparison with that realized in 2008. This was mainly due to the decrement of the trade participation of the two greatest traders within the free trade area-Croatia and Serbia.

At the end of 2008, Croatia registered an enormous deficit in the balance of payments and declared to be at the brink of a bankruptcy. The economy had to implement certain restrictive measures to prevent the catastrophe, and started to limit imports from all trading partners, including CEFTA-2006.

Serbia faced a very bad macroeconomic situation and a huge balance of payments deficit which pushed her to look for a new IMF arrangement. As in the case of Croatia, here also were imposed various restrictions and additional limitations to the free trade exchange of goods.

All of the rest of the member-states have significantly smaller economic potential, and though they have suffered from the crises and decreased their trade exchange of goods, they have not experienced a significant 
effect upon the trade exchange of goods within the free trade area. The effects upont the total export and import of goods realized with the creation of the free trade area, as well as from the crises in 2008 could be followed up in the below presented in Table 3 .

Table 3

Trade Exchange of Goods of the Republic of Macedonia and CEFTA-2006 Member Sates (in Million Dollars) *

\begin{tabular}{|c|c|c|c|c|c|c|c|c|c|c|c|c|}
\hline \multirow{2}{*}{ Year } & \multicolumn{2}{|c|}{ Serbia } & \multicolumn{2}{|c|}{ Croatia } & \multicolumn{2}{|c|}{$\mathrm{B} \& \mathrm{H}$} & \multicolumn{2}{|c|}{ Albania } & \multicolumn{2}{|c|}{ Moldavia } & \multicolumn{2}{|c|}{ Monte Negrc } \\
\hline & $\mathrm{E}$ & I & $\mathrm{E}$ & I & $\mathrm{E}$ & I & $\mathrm{E}$ & I & $\mathrm{E}$ & I & E & I \\
\hline 2001 & 266.94 & 189.41 & 58.49 & 46.49 & $6.04^{*}$ & $8.46^{*}$ & $9.77^{*}$ & $0.56^{*}$ & - & - & - & - \\
\hline 2002 & 245.21 & 189.41 & 59.08 & 5.36 & 19.20 & 14.30 & 13.86 & 1.13 & - & - & - & - \\
\hline 2003 & 273.80 & 215.73 & 66.10 & 63.67 & 20.83 & 11.75 & 15.34 & 3.93 & - & - & - & - \\
\hline 2004 & 347.60 & 243.72 & 80.16 & 65.78 & 33.22 & 16.31 & 23.59 & 6.35 & $0.4^{*}$ & $0.32^{*}$ & - & - \\
\hline 2005 & 459.54 & 264.20 & 81.05 & 75.23 & 50.46 & 23.58 & 27.52 & 9.07 & 0.06 & 0.27 & - & - \\
\hline 2006 & 557.85 & 282.85 & 124.23 & 78.96 & 64.70 & 26.53 & 40.56 & 11.72 & 0.17 & 0.13 & - & - \\
\hline 2007 & 639.42 & 448.40 & 163.87 & 109.74 & 88.02 & 34.52 & 72.69 & 19.52 & 0.04 & 0.18 & 27.69 & 1.34 \\
\hline $2008^{* *}$ & 934.72 & 532.02 & 228.96 & 137.71 & 104.84 & 52.60 & 106.77 & 35.66 & 0.03 & 3.36 & 38.57 & 1.21 \\
\hline 2009 & 337.59 & 397.05 & 152.72 & 118.34 & 86.64 & 46.53 & 83.95 & 24.10 & 0.09 & 2.93 & 24.88 & 1.18 \\
\hline 2010 & 271.82 & 418.39 & 123.62 & 113.28 & 84.94 & 49.12 & 72.38 & 22.89 & 0.35 & 0.92 & 27.43 & 1.43 \\
\hline
\end{tabular}

Notes. ${ }^{*}$ As the free trade agreements with Bosnia and Herzegovina (B\&H) and with Albania were enforced in 2002, data on 2001 are given only for comparison purposes. ${ }^{* *}$ Until 2008 data on trade exchange of goods of Macedonia with Serbia also comprised the trade exchange with Kosovo. The total Macedonian exports to Kosovo in 2009 amounted 314.54 million dollars, and the total import from Kosovo amounted 9.65 million dollars. In 2010, the realized export to Kosovo reached 437.77 million dollars, and the import from Kosovo amounted 22.05 million dollars (Retrieved from www.statistics.gov.mk).

Due to the crises the participation of the trade exchange of goods of CEFTA-2006 in the total Macedonian trade exchange of goods in 2009 decreased to $20 \%$. Thereby, CEFTA-2006 created 37.2\% of total Macedonian exports and only $11.9 \%$ of total Macedonian imports. Even under this inconvenient circumstances Macedonia realized a trade surplus of about 400 million dollars. The realized surplus in the trade with CEFTA-2006 in 2009, as shown in Table 4, was smaller than the one realized in 2008 of 38.6\% (Retrieved from www.statistics.gov.mk).

Table 4

Indexes of Trade Exchange of Goods of the Republic of Macedonia With Trade-Partners From CEFTA-2006 for the Period of the Economic Crises

\begin{tabular}{|c|c|c|c|c|c|c|c|c|c|c|c|c|c|c|c|c|c|}
\hline \multirow{2}{*}{ Year } & \multicolumn{7}{|c|}{ Indexes on exports by country } & \multicolumn{7}{|c|}{ Indexes on imports by country } & \multicolumn{3}{|c|}{ Total } \\
\hline & A & $\mathrm{B} \& \mathrm{H}$ & $\mathrm{C}$ & $\mathrm{MN}$ & $\mathrm{MO}$ & $\mathrm{S}$ & $\mathrm{K}$ & A & $\mathrm{B} \& \mathrm{H}$ & $\mathrm{C}$ & $\mathrm{MN}$ & MO & $\mathrm{S}$ & $\mathrm{K}$ & $\mathrm{E}$ & $\mathrm{I}$ & $\mathrm{E}+\mathrm{I}$ \\
\hline $2009 / 2008$ & 78.6 & 82.6 & 66.7 & 64.5 & 324.4 & 36.1 & na & 67.6 & 88.4 & 85.9 & 144.4 & 87.1 & 74.6 & na & 70.7 & 78.7 & 73.5 \\
\hline $2010 / 2009$ & 86.2 & 98 & 80.9 & 110.2 & 387.1 & 80.5 & 139.1 & 95 & 105.5 & 95.7 & 82.1 & 31.5 & 105.3 & 228.3 & 101.7 & 104.6 & 102.8 \\
\hline
\end{tabular}

Statistical data for 2010 confirm that there was a slight recovery of the economic activity within the region which had a positive influence upon the trade exchange of goods among the member states. However, in comparison with 2009 total Macedonian trade within CEFTA-2006 increased by only $2.8 \%$ and reached the amount of 1.64 billion dollars, of which 1.018 billion dollars was the amount of the realized export, and 0.628 billion dollars was the amount of the realized import. Most of the increment of the Macedonian trade within the region was due to the increment of the trade with Kosovo (of $41.8 \%$ ) and with Monte Negro (of $8.4 \%$ ). At the end of 2010, Macedonian export to CEFTA-2006 member-states created 31\% of the total Macedonian export 
(Retrieved from www.statistics.gov.mk).

\section{Analyses of the Structure of Traded Goods Under the Preferential Trade Regime of CEFTA-2006}

CEFTA-2006 consists of member-states that have poor individual economic capacity mainly due to the inconvenient and backward inherited economic structure and a very limited market potential of each of the national economies. However, even more important is the fact that each of them is facing low competitiveness of industrial production which seriously affects exports from the region on foreign markets. The law competitiveness of production is a problem even on their domestic markets, as most of the domestic industries are incapable to face competition of imported products. One of the most recent reports of the World Economic Forum made a ranking of 131 countries from the world on a global competitiveness list. On this list, the best ranked country from CEFTA-2006 is Monte Negro positioned on the 62nd place, followed by Croatia which is ranked on the 72nd place and by Macedonia, ranked on the 84th place. Bosnia and Herzegovina and Serbia have weaker positions than Macedonia on this list (Retrieved from www.mchamber.mk).

Having similar economic structure and facing similar competitiveness problems, most of the CEFTA-2006 member-states try to use the preferential trade regime of this free trade agreement to provide placement of various, mostly unprocessed agricultural products. The agreement provides such a possibility not only because it integrates countries with a very close geographic proximity, but also because different countries from the region export different agricultural products and depend on the import of others.

Data presented in Table 5 clearly point out the heavy dependence of CEFTA-2006 member-states on exports of agricultural goods. But there is also a significant interdependence of exports of non-agricultural goods. This conclusion is, though, not true for two member-states-Albania and Moldavia. Both of them did not belong to the Yugoslav federation and have much greater dependence on export of agricultural and non-agricultural goods to partners from the EU.

The interdependence of member-states at the import side is much less intensive, especially after the beginning of the economic crises at the end of 2008. Looking at data on import of non-agricultural goods within the region one can notice that most of the countries recorded less that $10 \%$ of their total import of these products from the region. The exclusion from this rule were Bosnia and Herzegovina and Monte Negro that depended on about $30 \%$ of their total trade exchange of non-agricultural goods and on more than $2 / 3$ of their total trade exchange of agricultural goods from the region. Available data from 2008 up-to-date show even greater interdependence on both groups of products in the case of Kosovo (Kikerkova, 2009).

It is also important to point out that member-states tend to mutually exchange non-agricultural products with lower level of finalization, such as iron and steel; products of iron and steel; mineral fuels, non-metal products, plastics and products made thereof; etc.. The only two member-states that are exchanging to a greater extent finalized industrial products, such as electrical equipment and machinery are Serbia and Croatia.

The export and the import of industrial goods from all member states are rather fragmented and extensive. But, even more important is the fact that basically the pattern of trade exchange of non-agricultural goods within CEFTA-2006 is still inter-industrial, which additionally confirms the very low capacity of industrial production of each of the economies and their inefficiency and low level of productivity (see Table 5 and Table 6). For a 
comparison, at the beginning of 2000, the member-states of the old CEFTA (Poland, Check Republic, Slovakia, Hungary, Slovenia, Romania and Bulgaria) achieved intra-industrial pattern of trade among them, but they also had the same pattern of trade with the EU partner countries (Kikerkova, 2010).

Table 5

Data on Exports of Agricultural and Non-agricultural Goods Among CEFTA-2006 Members and Their Total World Trade ${ }^{* *}$

\begin{tabular}{|c|c|c|c|c|c|c|c|c|c|c|c|c|}
\hline & \multicolumn{2}{|c|}{ Albania } & \multicolumn{2}{|c|}{$\mathrm{B} \& \mathrm{H}$} & \multicolumn{2}{|c|}{ Croatia } & \multicolumn{2}{|c|}{ Macedonia } & \multicolumn{2}{|c|}{ Moldavia } & \multicolumn{2}{|c|}{ M. Negro } \\
\hline & 2007 & $2008^{*}$ & 2007 & $2008^{*}$ & 2007 & $2008^{*}$ & 2007 & $2008^{*}$ & 2007 & $2008^{*}$ & 2007 & $2008^{*}$ \\
\hline $\begin{array}{l}\text { Total exp. of AG } \\
\text { products } \\
\text { CEFTA-2006 }\end{array}$ & $17.54 \%$ & $6.65 \%$ & $70.52 \%$ & $75.60 \%$ & $43.92 \%$ & $46.84 \%$ & $48.23 \%$ & $54.72 \%$ & $1.29 \%$ & $3.13 \%$ & $89.64 \%$ & $94.30 \%$ \\
\hline $\begin{array}{l}\text { Total exp. of AG } \\
\text { products of the } \\
\text { world (in mill. } \\
\text { EUR) }\end{array}$ & 57.23 & 38.00 & 166.10 & 86.24 & 953.57 & 411.50 & 468.71 & 265.28 & 371.22 & 156.01 & 53.17 & 24.93 \\
\hline $\begin{array}{l}\text { Total exp. of } \\
\text { non-AG products } \\
\text { CEFTA-2006 }\end{array}$ & $4.58 \%$ & $6.06 \%$ & $33.80 \%$ & $34.43 \%$ & $19.58 \%$ & $20.93 \%$ & $26.52 \%$ & $31.54 \%$ & $0.27 \%$ & $0.43 \%$ & $23.41 \%$ & $27.64 \%$ \\
\hline $\begin{array}{l}\text { Total exports of } \\
\text { non-AG products } \\
\text { of the world (in } \\
\text { mill. EUR) }\end{array}$ & 727.46 & 665.62 & $2,869.2$ & $1,626.3$ & $8,097.9$ & $4,191.5$ & $2,887.5$ & $1,804.7$ & 609.89 & 326.90 & 577.86 & 232.58 \\
\hline $\begin{array}{l}\text { Total exp. from } \\
\text { CEFTA-2006 }\end{array}$ & $14.79 \%$ & $6.09 \%$ & $35.81 \%$ & $36.50 \%$ & $22.27 \%$ & $24.23 \%$ & $29.55 \%$ & $34.51 \%$ & $0.65 \%$ & $1.30 \%$ & $28.99 \%$ & $34.10 \%$ \\
\hline $\begin{array}{l}\text { Total exports } \\
\text { from the world } \\
(100 \%)\end{array}$ & 784.09 & 703.62 & $3,035.3$ & $1,712.6$ & $9,001.6$ & $4,603.0$ & $3,356.2$ & $2,070,0$ & 981.12 & 482.92 & 631.03 & 257.51 \\
\hline
\end{tabular}

Notes. ${ }^{*}$ Data for 2008 are accounted only for the first six months of the year. ${ }^{* *}$ Due to methodological problems of incomparability, data on Serbian trade exchange within the region are not included in the table.

Table 6

Data on Imports of Agricultural and Non-agricultural Goods Among CEFTA-2006 Members and Their Total World Trade ${ }^{* *}$

\begin{tabular}{|c|c|c|c|c|c|c|c|c|c|c|c|c|}
\hline & \multicolumn{2}{|c|}{ Albania } & \multicolumn{2}{|c|}{$\mathrm{B} \& \mathrm{H}$} & \multicolumn{2}{|c|}{ Croatia } & \multicolumn{2}{|c|}{ Macedonia } & \multicolumn{2}{|c|}{ Moldavia } & \multicolumn{2}{|c|}{ M. Negro } \\
\hline & 2007 & $2008^{*}$ & 2007 & $2008^{*}$ & 2007 & $2008^{*}$ & 2007 & $2008^{*}$ & 2007 & $2008^{*}$ & 2007 & $2008^{*}$ \\
\hline $\begin{array}{l}\text { Total imp. of AG } \\
\text { products } \\
\text { CEFTA-2006 }\end{array}$ & $6.42 \%$ & $5.67 \%$ & $50.76 \%$ & $86.83 \%$ & $8.18 \%$ & $7.18 \%$ & $33.78 \%$ & $30.15 \%$ & $0.25 \%$ & $0.17 \%$ & $73.44 \%$ & $78.84 \%$ \\
\hline $\begin{array}{l}\text { Total imp. of AG } \\
\text { products of the } \\
\text { world }(100 \%) \text { in } \\
\text { mill. EUR }\end{array}$ & 506.94 & 295.48 & $1,144.7$ & 635.79 & $1,564.4$ & 853.28 & 622.95 & 387.57 & 340.68 & 209.15 & 262.92 & 145.37 \\
\hline $\begin{array}{l}\text { Total imports of } \\
\text { non-AG products } \\
\text { CEFTA-2006 }\end{array}$ & $6.39 \%$ & $7.32 \%$ & $24.91 \%$ & $49.42 \%$ & $4.76 \%$ & $4.59 \%$ & $8.76 \%$ & $8.77 \%$ & $0.18 \%$ & $0.27 \%$ & $41.7 \%$ & $52.67 \%$ \\
\hline $\begin{array}{l}\text { Total imports of } \\
\text { non-AG products of } \\
\text { the world }(100 \%) \text { in } \\
\text { mill. EUR }\end{array}$ & $2,541.7$ & $1,356.9$ & $5,961.3$ & $3,443.2$ & $17,262.1$ & $9,650.3$ & $4,604.6$ & $3,132.0$ & $2,357.3$ & $1,317.4$ & $1,720.9$ & 808.58 \\
\hline $\begin{array}{l}\text { Total imports from } \\
\text { CEFTA-2006 }\end{array}$ & $6.39 \%$ & $7.02 \%$ & $29.08 \%$ & $55.25 \%$ & $5.04 \%$ & $4.80 \%$ & $11.74 \%$ & $11.12 \%$ & $0.19 \%$ & $0.26 \%$ & $45.92 \%$ & $56.66 \%$ \\
\hline $\begin{array}{l}\text { Total imports from } \\
\text { the world }(100 \%) \text { in } \\
\text { mill EUR }\end{array}$ & $3,048.74$ & $1,652.4$ & $7,106.0$ & $4,079.0$ & $18,826.5$ & $10,503.6$ & $5,227.5$ & $3,519.6$ & $2,698.0$ & $1,526.6$ & $1,983.8$ & 953.96 \\
\hline
\end{tabular}

In the case of CEFTA-2006, the slow economic reintegration of the region is evident also from the fact that 
the countries from the region are trading far more intensively with other trade partners (for example over $50 \%$ of their total trade exchange is done with the EU countries) than among them. In their mutual trade, each of the countries relies upon two or at most three trade partners from the region. For Bosnia and Herzegovina and Monte Negro the most important CEFTA-2006 trade partners are Serbia and Croatia; for Serbia-Bosnia and Herzegovina and Macedonia, for Croatia-Serbia and Bosnia and Herzegovina, and for Macedonia-Serbia, Croatia and Kosovo (Kikerkova, 2009).

All the weaknesses of the economies of the member-states prevent the realization of the full benefits of trade liberalization, as well as the realization of the full economic potential of the region. The economic crises additionally emphasized the weaknesses of the CEFTA-2006 economies. Even before the crises, it was evident that some of the countries tried to apply additional barriers to trade, which fortunately was prevented by a quick reaction from the rest of the members. Having this experience on mind, right after the start of the crises, some of the countries in the region tried to restrict the free trade in the region with non-trade barriers, but also there were attempts to implement measures that are not up to the provisions of the signed agreement. Some of the member-states did not fully respect the provisions on harmonization and mutual recognition of sanitary and phytosanitary standards and used them to prevent imports of agricultural products. Last year, this measure was especially used by Bosnia and Herzegovina. The lower production of cereals in the world made some of the greatest cereal producers in the region to impose a ban on exports of this kind of products in order to preserve their own national reserves. Serbia implemented higher excise on imports of mineral fuels, which is not only in collusion with the CEFTA-2006 Agreement, but also colludes with the signed Stabilization and Association Agreement with the EU (Retrieved from www.mchamber.mk).

\section{Measures on Trade Facilitation Within CEFTA-2006}

As it was already mentioned, the EU insisted on the creation of at least a free trade area among Western Balkan countries as the only way to circumvent the multilaterally regulated rules of origin and to provide special rules of origin for imports under preferential trade regime from this part of Europe. The special rules on proving the origin is called "diagonal cumulation" and has been already used for making preferential trade regime available for Central and Eastern European exporters to the EU.

In the case of CEFTA-2006, the diagonal cumulation of origin is available:

- Among CEFTA-2006 member-states. For example, Serbia imports components from Bosnia and Herzegovina, processes them in its industry and exports the final product in Macedonia without having to prove Serbian origin;

- If the country has signed the CEFTA-2006 Agreement and has also signed a Stabilization and Association Agreement with the EU. At present Kosovo and Moldova have not such an agreement with the EU, and in Bosnia and Herzegovina this agreement is non-functional. The countries that have a functional agreement are able to exchange raw materials and components among them and the country that is going to put them all together into a final product may export it to the EU as a national product without having proved its origin. For example, Macedonia may export tomatoes to Croatia from which Croatia produces tomato juice. This juice could be exported to the EU as a Croatian product and use the preferential treatment of import that the EU provides to Croatia under the signed Stabilization and Association Agreement; 
- If the member-state of CEFTA-2006 has a Stabilization and Association Agreement with the EU and has also signed a free trade agreement with EFTA-countries and Turkey, then the diagonal cumulation of origin is also valid for those countries. In the case of Macedonia, this was especially important, as the woven and clothes for the textile industry are imported from Turkey. Therefore, textile exporters could not prove Macedonian origin of final products and could not export textile from Macedonia to the EU under the preferential trade regime provided by the Stabilization and Association Agreement. Though, this kind of diagonal cumulation is not fully operable as not all of the CEFTA-2006 members have a free trade agreement with the EFTA and with Turkey. Such is the case with Kosovo, and Serbia and Monte Negro have not such an arrangement with Turkey, yet. In order to overcome this problem an entry in the Pan-Euro-Med Agreement on Free Trade is reconsidered also for Western Balkan countries (Retrieved from www.mchamber.mk; Handziski, 2010).

It is obvious that the diagonal cumulation of origin is not fully functional, yet. However, it still provides trade facilitation to a certain degree which was not available before for the trade exchange within the region and the trade exchange with the EU.

Improved cooperation among Customs Administrations of the member states and the facilitation of customs and transit procedures is expected to contribute for a significant intensification of the trade exchange and speeding up the cross-border flow of goods. The new rules of international trade impose the need of the establishment of paperless effectuation of export/import of goods. This means establishment of electronic forms and electronic signature of necessary documents. Therefore, the Customs Administrations of CEFTA-2006 members should provide electronic equipment and customs network connection for which a substantial financial support should be provided. Financial means are also necessary for the modernization and adaptation of the customs borders up to the EU standards. The possibility of opening of new border crossings among neighboring countries in the region should be taken in consideration, as well.

In November 2010, during the Week of CEFTA-2006 in Belgrade, the new CEFTA Trade Portal was promoted. The Portal should provide all relevant information not only on different export and import procedures of the CEFTA-2006 member states, but should also provide on-line availability of all forms and documents needed for completion of the customs procedure. This should save a lot of time, speed up movement of goods and passengers across borders and cut down unnecessary costs on export/import within the region (Retrieved from www.mchamber.mk).

At the beginning of this year, the member states signed an agreement on unification on transit procedures within the region. Serbia even proposed (and Monte Negro and Bosnia and Herzegovina supported the proposal) that movement of persons should be allowed only with a valid identification card, instead of a passport. However, the free movement of persons for some of the member states is not possible as they have to apply for a visa. Such is the case between Macedonia and Moldova, and representatives from both countries met at the end of March 2011 in order to discuss possible liberalization of the visa regime (Retrieved from www.mchamber.mk).

The Tax Administrations of Serbia, Monte Negro, Bosnia and Herzegovina and Slovenia (an EU member-state) signed an agreement on mutual cooperation and exchange of information in order to prevent tax evasion and the functioning of the gray economy (Kapital, 2011).

Special attention draws the creation of the Interchamber CEFTA-Working Group on Insurance. The working group was created at the beginning of March 2011 in Belgrade in order to provide gradual liberalization 
of the trade regulative and abolishment of administrative barriers. It should analyze the existing regulative, problems and barriers to providers of insurance services within CEFTA-2006. It is also opening the question of the establishment of co-insurance services among member states. The creation of the Interchamber CEFTA-Working Group is considered to be a significant signal on the enhanced activity of member states in the sphere of services (Retrieved from www.mchamber.mk).

However, the fragile economic and political situation of the Western Balkan countries and the complicated economic and political situation in the world do not allow the member-states to use the real economic potential of the signed multilateral free trade agreement to its full extent. The latest news from the region confirm that Serbia has declared a three months ban on the export of wheat and flour because it has already exported about 150,000 tons of wheat more than it was planned for the whole 2011. Considering the unstable supply of the Serbian market, as well as the situation on the world wheat market, the Serbian government has brought this decision in consultation with the CEFTA-2006 member-states and the CEFTA-2006 Headquarters in Brussels (Kapital, 2011)

\section{Conclusion}

The multilateral trade agreement CEFTA-2006 replaced 32 bilateral free trade agreements in the region of Western Balkans. The establishment of a full free trade area among its member states had to be completed at the end of 2010. This multilateral agreement should facilitate not only the trade exchange of goods, but also the trade of services and intellectual property. It should also help the harmonization of sanitary and phytosanitary measures according to the WTO standards, implementation of the TBT agreement and simplification of the rules of origin.

The creation of the free trade area intensified the trade exchange of goods among its member-states, though not to the extent that is up to the full economic potential of the region and its traditional trading links. Data on trade exchange undoubtedly confirm that by increasing their mutual trade within CEFTA-2006 almost all of the countries registered a slight decrement in the trade with other countries, especially with the EU. This is also a confirmation of the weakness and low capacity of their economies, as well as of lack of competitiveness of their industrial production. The Western Balkan countries still follow the inter-industrial pattern of trade within their own region, but also with trade partners from the EU, which is additional confirmation of the backwardness of the structure of their economies and their weak economic capacity and lack of competitiveness.

All of the ex-Yugoslav states find the region as a very important market for export of their agricultural output. The region shows however much lower interdependence on the trade exchange of non-agricultural goods.

The exchange of non-agricultural goods consists mostly of iron and steel, iron and steel products, mineral fuels, plastics and similar goods that have low level of industrial finalization. Croatia and Serbia figure as exporters of some electrical equipment and machinery, which also implies for Bosnia to a certain extent. However, both the export and the import of industrial goods from all member states are rather fragmented and extensive, which confirms the very low capacity in industrial production of each of the economies and their inefficiency and low level of productivity. The inability to provide more sophisticated processed goods on their domestic and regional market orients these countries to depend significantly on imports of such products from Western European economies.

It is important to point out that each of the member states depends on trade exchange of goods only on one or two major trading partners from the region, while the cooperation with the rest of the member states is 
insignificant.

The inconvenient events in the world economy, the catastrophe in Japan and the political instability of the Arabic countries make the situation on the Balkans even more fragile than before. Although CEFTA-2006 makes a lot of efforts to improve mutual cooperation and liberalize the trade exchange of goods and services, the danger of an outburst of new economic crises makes its member states react as sea shells ready to close immediately if they find themselves in any situation of a potential jeopardy.

\section{References}

According to The Economic Chamber of the Republic of Macedonia. (2009, 2010). E-Informator. Retrieved from www.mchamber.mk

According to the Ministry of Economy of the Republic of Macedonia and the USAID. (2008). Report on Foreign Trade of Macedonia 2008. Ministry of Economy of the Republic of Macedonia and the USAID, Skopje, 2008, (p. 67)

The Economic Chamber of the Republic of Macedonia. (2008). E-Informator. Retrieved from www.mchamber.mk

Calculated on basis of data from the Mission of the Republic of Macedonia in Brussels. (2009, March). Statistical Data on CEFTA-2006 Trade Exchange (pp. 1-8). Ministry of Foreign Affairs of the Republic of Macedonia, Skopje.

Hadnziski, B., Lucas, R., Martin, P., \& Gunerin, S. S. (2010, January). Enhancing Regional Trade Integration in Southeast Europe, World Bank Working Paper No.185 (pp. 18, 20), the World Bank, Washington D.C..

Hadnziski, B., Lucas, R., Martin, P., \& Gunerin, S. S. (2010, January). Enhancing regional trade integration in Southeast Europe, World Bank Working Paper No.185 (p. 39). World Bank, Washington D.C..

Kapital Media Group, Kapital. (2011, March 18). “Заедно против даночната евазија” ("Toghether against tax evasion”) and “Србија го забрани извозот на пченица" (“Srbia bans the export of wheat”) (p. 9). Skopje.

Kikerkova, I. (2009). CEFTA-2006 as basis for economic reintegration of Western Balkan countries. Third International Conference on Regional Cooperation and Economic Integration. Challenges and opportunities (p. 158). Ss. Cyril and Methodius University, Faculty of Economics-Skopje, October 15-17, Skopje.

Kikerkova, I. (2009, October 15-17). CEFTA-2006 as basis for economic reintegration of Western Balkan countries. Third International Conference on Regional Cooperation and Economic Integration-challenges and opportunities (pp. 166-167). Ss. Cyril and Methodius University, Faculty of Economics-Skopje, Skopje.

Kikerkova, I. (2010). CEFTA-2006 effects upon the Macedonian foreign trade exchange. In V. Kandzija, \& A. Kumar (Eds.), Economic integrations, competition and cooperation (p. 100). University of Ljubljana, Faculty of Economics, Jean Monnet Chair; University of Antwerp, Jean Monnet Centre of Excellence and the Institute CEDIMES Paris, CEDIMES Rijeka.

Ministry of Economy of the Republic of Macedonia and the USAID. (2008). Report on Foreign Trade of Macedonia 2008 (pp. 67-78), Skopje.

The Chamber of Commerce of the Republic of Macedonia. (2010, Juanary 4). Report on CEFTA-2006 (p. 4). Skopje.

The Economic Chamber of the Republic of Macedonia. (2010). E-Informator. Retrieved from www.mchamber.mk

The Economic Chamber of the Republic of Macedonia. (2011). E-Informator. www.mchamber.mk

The Ministry of Economy of the Republic of Macedonia and the USAID. (2008). Report on Foreign Trade of Macedonia 2008. Ministry of Economy of the Republic of Macedonia and the USAID, (pp. 68-78) and the Statistical Office of the Republic of Macedonia (2008), Statistical Yearbook 2008. Retrieved from www.statistics.gov.mk

The Statistical Office of the Republic of Macedonia. (2009, 2010). Statistical Yearbook 2009 \& 2010. Retrieved from www.statistics.gov.mk 